\title{
Perceptions of E-commerce Web Sites across Two Generations
}

\author{
Terry J. Smith and Richard Spiers \\ Macon State College, Macon, GA, USA
}

terry.smith1@maconstate.edu; richard.spiers@maconstate.edu

\begin{abstract}
Numerous studies have examined and predicted the usage of e-commerce Web sites using the Technology Acceptance Model and its primary constructs of perceived usefulness and perceived ease of use. Smith (2008) conducted an empirical study of four e-commerce Web sites with participation from a unique and often understudied segment of the population - the senior generation. In addition, he called for additional research on the same e-commerce Web sites with participants from today's student population, a generation that has grown up with computers and the Internet. During the Spring 2008 semester, the authors duplicated Smith's research and conducted a field experiment with a purposeful sample of students enrolled in four courses in the School of Information Technology at Macon State College. Consistent with the conclusion by Smith, of significant worth is the test of the robustness of the Technology Acceptance Model (TAM) when applied to e-commerce adoption by both the senior generation and the net generation. The model's predictive and explanatory capabilities still hold true. This is the only study we know of that compares two generations and their perceptions of e-commerce Web sites.
\end{abstract}

Keywords: Technology Acceptance Model, Web site usability, E-commerce, Senior generation, Net generation

\section{Introduction}

The Informing Science framework consists of three distinct parts: the informer, the delivery mechanism, and the client (E. B. Cohen, 1999). E-commerce vendors (the informers) communicate to and interact with the customers (clients) of the vendor's products and services. This is achieved through a delivery mechanism that is composed of three parts: the Web site infrastructure, its human-computer interfaces, and the communication medium - the Internet. Gill (2008), through a client resonance model, states that the client's initial mental model of the informing system is altered by a series of filters based on various biological, psychological, motivational, and visceral elements and factors. Based on Gill's model, the informer's goal, via the design of the

Material published as part of this publication, either on-line or in print, is copyrighted by the Informing Science Institute. Permission to make digital or paper copy of part or all of these works for personal or classroom use is granted without fee provided that the copies are not made or distributed for profit or commercial advantage AND that copies 1) bear this notice in full and 2) give the full citation on the first page. It is permissible to abstract these works so long as credit is given. To copy in all other cases or to republish or to post on a server or to redistribute to lists requires specific permission and payment of a fee. Contact Publisher@,InformingScience.org to request redistribution permission. delivery mechanism, is to acquire the client's attention and then to motivate the client to engage in the informing process.

Vendors have choices in terms of the technologies they use to develop and support their Web sites but face challenges in designing Web sites that effectively and efficiently inform many different users with different levels of 
computer knowledge and Internet experience, differing demographic profiles, and the presence of sensory, cognitive, or mobility impairments. It is the human-computer interfaces that communicate information to the customers, and it is through the interfaces that customers purchase the vendor's products and services, thus communicating information back to the vendor. The success of this information exchange is dependent on the customers' mental model of the Web site, influenced by the customers' perceptions of the usefulness of the Web site and how easy the Web site is to use.

Numerous studies have examined and predicted the usage of e-commerce Web sites using the Technology Acceptance Model and its primary constructs of perceived usefulness and perceived ease of use. The Technology Acceptance Model (TAM) (see Figure 1) states that the success of a system can be determined by user acceptance of the system, measured by two variables: the Perceived Usefulness of the system and the Perceived Ease of Use of the system (Davis, 1989). According to the TAM, a user's perceptions about a system's usefulness and ease of use result in an intention to use or not use the system (Davis, 1989; Venkatesh, 2000). It can be argued that a Web site's usefulness and ease of use act upon the filters, thereby acquiring the customer's attention and motivating the customer to use the system.

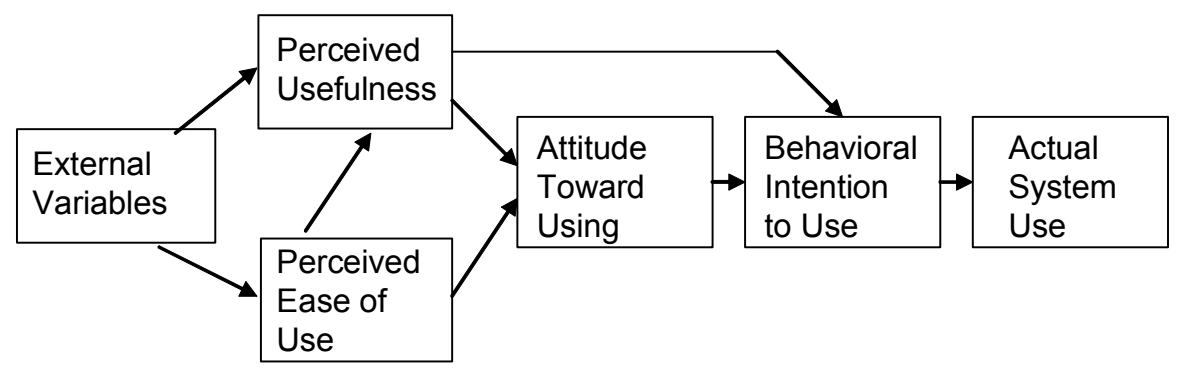

Figure 1. Technology Acceptance Model (TAM)

The TAM has been tested in many empirical studies (Burton-Jones \& Hubona, 2005), was found to be highly valid and reliable (Koufaris, 2000), and is widely referenced (Devaraj, Fan, \& Kohli, 2002). The external variables represent attributes or characteristics of the system, such as the overall design and features of the system; the user's computer skills, capabilities, and abilities; and the user's knowledge, beliefs, and attitude toward computers. Perceived usefulness is defined as "the degree to which a person believes that using a particular system would enhance his or her job performance" (Davis, 1989, p. 320). Perceived ease of use refers to "the degree to which a person believes that using a particular system would be free of effort" (p. 320).

Smith (2008) conducted an empirical study of four e-commerce Web sites with participation from a unique and often understudied segment of the population - the senior generation or people defined as 65 years of age and older (Fox, 2004). The research model that was used, showing hypotheses and construct relationships, is depicted in Figure 2. The null hypotheses (SGH) were as follows:

- SGH1: The senior's perception of the products and services offered by an e-commerce Web site will not have a significant effect on the senior's perceived usefulness of an ecommerce Web site.

- SGH2: The senior's perception of the perceived usefulness of an e-commerce Web site will not have a significant effect on the senior's attitude toward using an e-commerce Web site.

- SGH3: The senior's perception of the usability of an e-commerce Web site will not have a significant effect on the senior's perceived ease of use of an e-commerce Web site. 
- SGH4: The senior's perception of the usability of the Internet will not have a significant effect on the senior's perceived ease of use of an e-commerce Web site.

- SGH5: The senior's perceived ease of use of an e-commerce Web site will not have a significant effect on the senior's attitude toward using an e-commerce Web site.

- SGH6: The senior's perceived usefulness an e-commerce Web site will not have a significant effect on the senior's behavioral intention to use an e-commerce Web site.

- SGH7: The senior's perceived ease of use of an e-commerce Web site will not have a significant effect on the senior's perceived usefulness of an e-commerce Web site.

- SGH8: The senior's attitude toward using an e-commerce Web site will not have a significant effect on the senior's behavioral intention to use an e-commerce Web site.

- SGH9: The senior's behavioral intention to use an e-commerce Web site will not have a significant effect on predicting the senior's actual use of an e-commerce Web site.

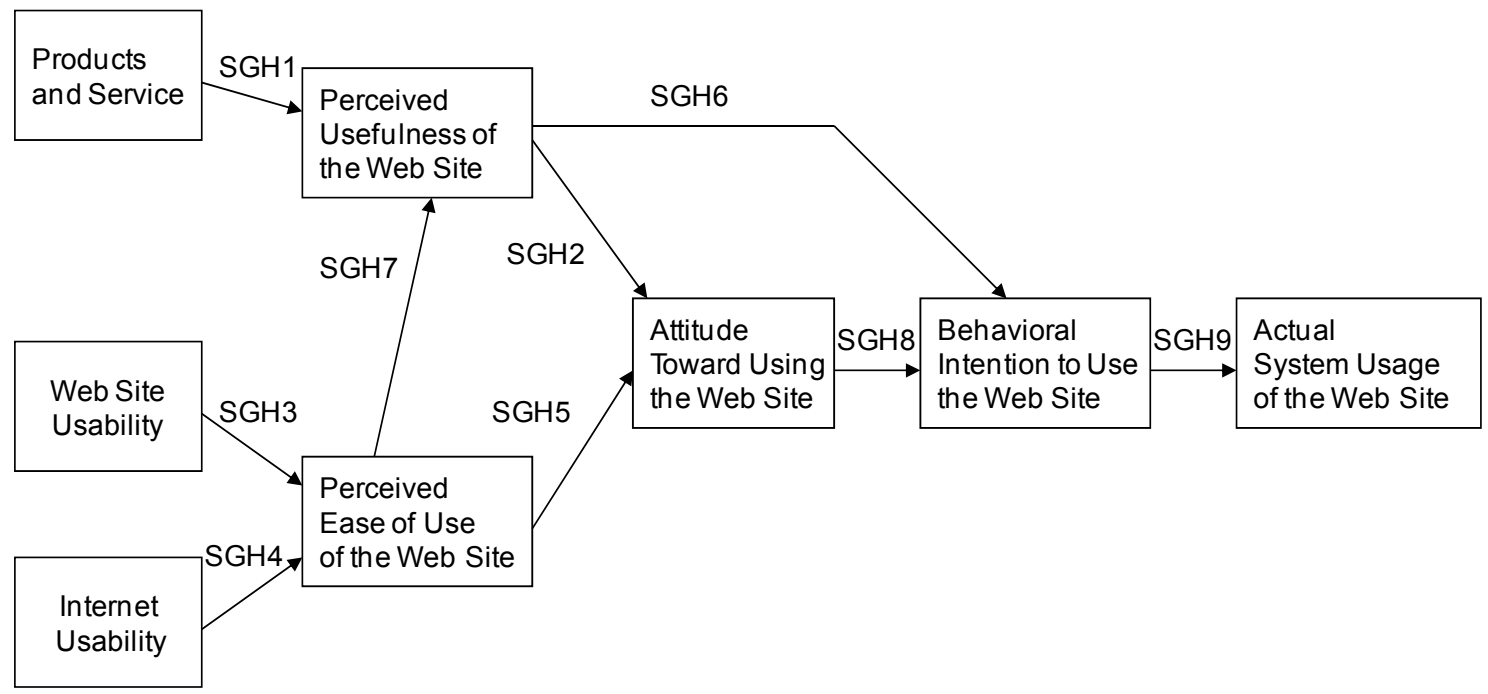

Figure 2. Research Model showing Hypotheses

Smith (2008) conducted the study with 21 participants from the senior generation, and then the data were input to PLS-Graph, a program that generates path coefficients, $t$ statistics, and variances using a bootstrapping resampling technique. The result of that analysis using the proposed research model is shown in Figure 3. The figure presents the path coefficients for the dependent and independent construct relationships and the amount of variance $\left(R^{2}\right)$ explained in the dependent constructs (Perceived Usefulness of the Web Site, Perceived Ease of Use of the Web Site, Attitude Toward Using the Web Site, Behavioral Intention to Use the Web Site, and Actual System Usage of the Web Site).

Smith (2008) found that when applied to e-commerce adoption by seniors, the TAM's predictive and explanatory capabilities held true. Four of the constructs were found to significantly influence a seniors' decision to use an e-commerce Web site. The constructs were the products and services offered by the vendor, the perceived usefulness of the Web site, Web site usability, and the influence of Internet usability on the perceived ease of use. 


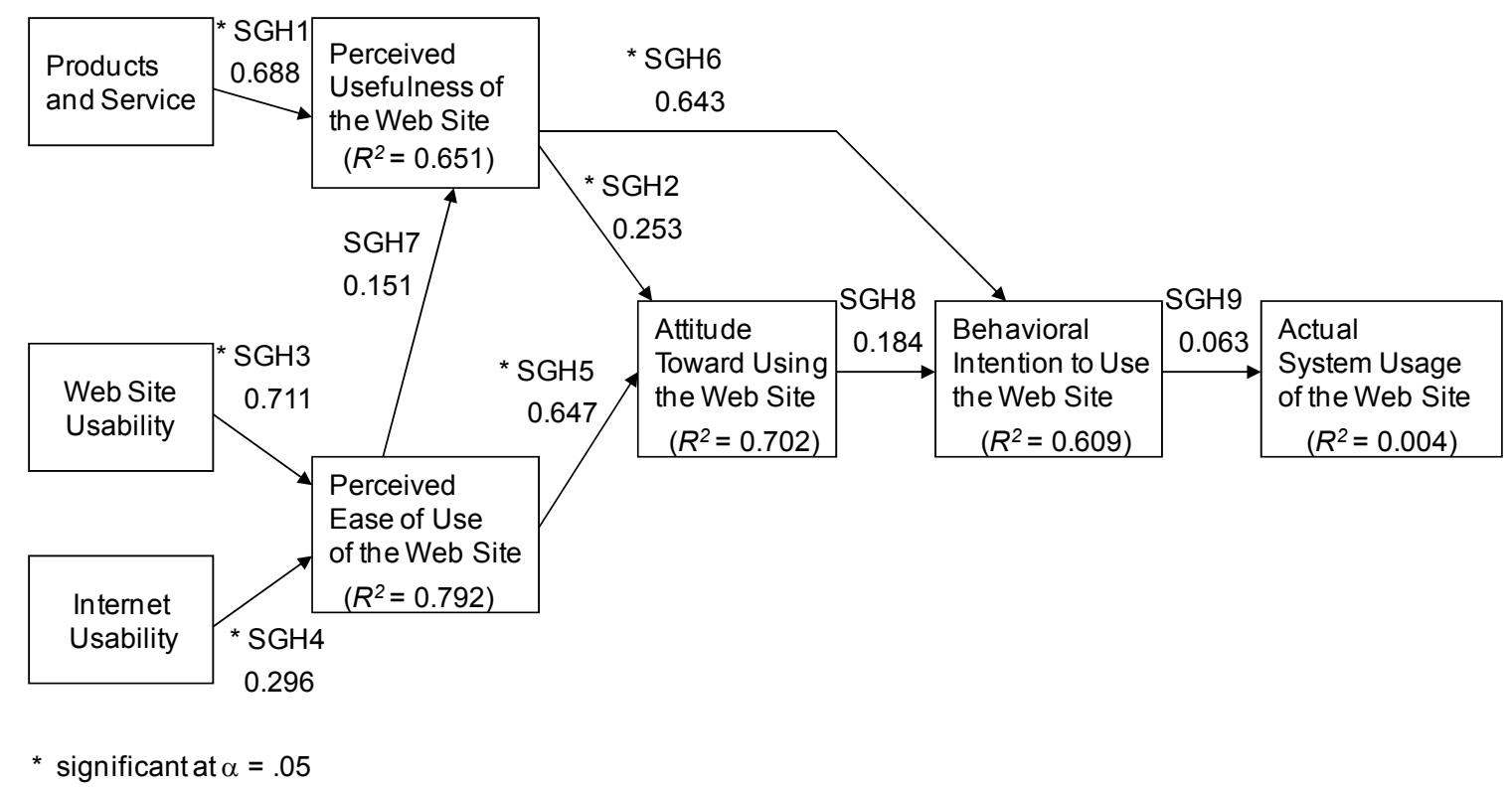

Figure 3. Hypotheses and Model Parameters for the Senior Generation

Smith $(2008$, p. 81) called for additional research on the same e-commerce Web sites with “...participants from today's student population, the generation that is increasingly using ecommerce and social Web sites through the Internet and the World Wide Web." This segment of the population, called the "Net Generation" (Rettie, 2002), is now 21 to 31 years of age and has grown up using computers and the Internet. Forty-nine students participated in this study and, using data from this study and from Smith's (2008) research conducted with the senior generation, this paper addresses the following two questions:

1. Are there any significant differences between the two generations' perceptions of ecommerce Web sites as defined by the research model?

2. Are there any significant differences between the two generations' perceptions of the construct relationships as defined by the research model?

\section{Related Work}

E-commerce Web sites are, according to Gefen, Karahanna, and Straub (2003), information technologies against which user acceptance behavior can be explained using the TAM. Online users, after all, are information technology users, and the more useful and easy to use the site, the more the Web site will be used. Within the body of research on the TAM, there are several studies that modified the TAM and focused on its use in predicting acceptance of the Internet and ecommerce systems.

Gefen, Straub, and Boudreau (2000) used a travel Web site, Travelocity.com, to test three constructs of the TAM: 1) perceived usefulness; 2) perceived ease of use; and 3) intention to use. The authors collected survey data from 160 students to compare and contrast three data analysis techniques: linear regression analysis, LISREL, and partial least squares. All three techniques produced the same result in that both perceived usefulness and perceived ease of use significantly influenced the intention to use the Web site.

Liang and Lai (2002) used three online bookstores in Taiwan: 1) Kingston.com.tw; 2)

Books.com.tw; and 3) Sanmin.com.tw. The goal was to examine the effects of each store's design on the consumer's decision to purchase from the Web site. Thirty students visited all three 
sites, purchased two items from any of the stores, and then completed a questionnaire about the pre-purchase and shopping experience. The results showed that store design was as important as the product's price and that consumers are more likely to purchase from well-designed Web sites.

Gefen et al. (2003) analyzed survey data collected from 196 graduate and undergraduate students. The data were captured on a questionnaire and the responses were based on the participant's last experience purchasing a book or CD from an online vendor. The authors were testing a model based on the TAM that included the constructs perceived usefulness, perceived ease of use, intended use, and a new construct, trust. The findings showed that trusting the Web site and the vendor is important and that the technological aspects of the Web site, specifically the interface, influenced both the initial decision to buy and then to return to the Web site in the future.

In an international setting, Singh, Fassott, Chao, and Hoffman (2006) tested a TAM that included a new construct, Cultural adaptation. The construct was posited to influence the TAM's Perceived ease of use of a Web site and the Attitude toward using a Web site. Cultural adaptation was defined as a Web site's ability s to present product content in formats applicable to different countries and cultures. The study showed that Cultural adaptation had a significant effect on the Perceived ease of use of the Web site, and that the remaining constructs in the TAM, Perceived usefulness and Perceived ease of use, were positively related to the Attitude toward using the Web site and ultimately the Behavioral intention to use the Web site.

Klopping and McKinney (2006) modified the TAM and examined the relationship between prior e-commerce shopping experience and the behavioral intention to shop online. A survey was completed by 826 undergraduate students at a university in the Midwest. The authors found that actual e-commerce shopping experience does have a positive and direct effect on a consumers' intention to shop online. The authors also found that self-efficacy, or the consumers' competence in using the Web to purchase goods and services had a stronger impact on the consumers' intention to shop online.

Ranganathan and Jha (2007) modified the TAM and examined the relationship between three constructs and the behavioral intention to shop online. The three constructs that were studied were prior e-commerce shopping experience, Web site quality, and computer self-efficacy. A survey was completed by 214 individuals, $60 \%$ of which were 21 to 30 years of age. Past experience with online shopping was found to have a significant positive influence on the behavioral intention to shop online. Web site quality and computer self-efficacy also were found to be strongly associated with the intention to shop online.

Savitskie, Royne, Persinger, Grunhagen, and Witte (2007) modified the TAM and added two constructs that were posited to influence the perceived usefulness of an e-commerce Web site. The authors added a construct Computer affinity to represent a user's attitude toward using computers. Also added to the model was a second construct, Involvement, to represent the user's attachment to the products offered for sale on an e-commerce Web site. An analysis of 292 responses to a questionnaire indicated that: 1) the construct Involvement had a significant effect on Perceived usefulness; and 2) Computer affinity did not have a significant effect on Perceived usefulness. Consistent with previous studies, Perceived usefulness was found to have a greater influence on the intention to use the Web site when compared to the Perceived ease of use of the Web site.

Morosan and Jeong (2008) modified the TAM and added a construct perceived playfulness. Perceived playfulness is defined as "...Web sites that are entertaining and fun and allow users to engage in their online experience" (p. 7). The study revealed that: 1) perceived usefulness and perceived ease of use can be used to predict attitudes toward using hotel Web sites; 2) perceived playfulness enhances the quality of the Web site; and 3) The TAM is appropriate for the study of hotel reservation Web sites in predicting a users' intention to use such Web sites. 
Hausman and Siekpe (2009) used a modified TAM to investigate the relationship of different Web site design elements on the constructs perceived usefulness and perceived ease of use. The authors categorized Web site design elements as a construct computer factors. The factors included such items as security and privacy policies, ease of navigation or flow, menu constructions, up-to-date product information and images, and simple yet complete order processes. These computer factors were found to directly influence the perceived usefulness of the Web site. Without the effective use of such elements, users may become irritated while using the Web site and may abandon the site without purchasing anything from the e-commerce vendor.

Finally, a study that compares Internet usage by multiple generations is not unique. Zaphiris and Sarwar (2006) studied the use of online newsgroups by teens and the senior generation. They found that "...online communities can provide support to their members (irrespective of age) on a plethora of topics" (p. 429). The authors also found that seniors tend to be more interactive and involved compared to the younger generation, forming stronger relationships with their peers.

In summary, the application of the TAM and its use when explaining the adoption of e-commerce Web systems has been established in prior studies. However, the authors did not find any research that compares the results of studies on e-commerce Web sites using participants from two generations - the senior generation and the net generation. Our study does that.

\section{Methodology}

\section{Research Questions and Hypotheses}

Hypotheses were established for each of the two research questions.

Research question 1: Are there any significant differences between the two generations' perceptions of e-commerce Web sites as defined by the research model?

- H1: The net generation's perception of the products and services offered by an ecommerce Web site will not have a significant effect on the net generation's perceived usefulness of an e-commerce Web site.

- H2: The net generation's perception of the perceived usefulness of an e-commerce Web site will not have a significant effect on the net generation's attitude toward using an ecommerce Web site.

- H3: The net generation's perception of the usability of an e-commerce Web site will not have a significant effect on the net generation's perceived ease of use of an e-commerce Web site.

- H4: The net generation's perception of the usability of the Internet will not have a significant effect on the net generation's perceived ease of use of an e-commerce Web site.

- H5: The net generation's perceived ease of use of an e-commerce Web site will not have a significant effect on the net generation's attitude toward using an e-commerce Web site.

- H6: The net generation's perceived usefulness of an e-commerce Web site will not have a significant effect on the net generation's behavioral intention to use an e-commerce Web site.

- H7: The net generation's perceived ease of use of an e-commerce Web site will not have a significant effect on the net generation's perceived usefulness of an e-commerce Web site. 
- H8: The net generation's attitude toward using an e-commerce Web site will not have a significant effect on the net generation's behavioral intention to use an e-commerce Web site.

- H9: The net generation's behavioral intention to use an e-commerce Web site will not have a significant effect on predicting the net generation's actual use of an e-commerce Web site.

Research question 2: Are there any significant differences between the two generations' perceptions of the construct relationships as defined by the research model?

- H10. There is not a significant difference between the two generations' perception of the relationship between the products and services offered by an e-commerce Web site and the perceived usefulness of an e-commerce Web site.

- H11: There is not a significant difference between the two generations' perception of the relationship between the perceived usefulness of an e-commerce Web site have and the attitude toward using an e-commerce Web site.

- H12: There is not a significant difference between the two generations' perception of the relationship between the usability of an e-commerce Web site and the perceived ease of use of an e-commerce Web site.

- H13: There is not a significant difference between the two generations' perception of the relationship between the usability of the Internet and the perceived ease of use of an ecommerce Web site.

- H14: There is not a significant difference between the two generations' perception of the relationship between the perceived ease of use of an e-commerce Web site and the attitude toward using an e-commerce Web site.

- H15: There is not a significant difference between the two generations' perception of the relationship between the perceived usefulness of an e-commerce Web site and the behavioral intention to use an e-commerce Web site.

- H16: There is not a significant difference between the two generations' perception of the relationship between the perceived ease of use of an e-commerce Web site and the perceived usefulness of an e-commerce Web site.

- H17: There is not a significant difference between the two generations' perception of the relationship between the attitude toward using an e-commerce Web site and the behavioral intention to use an e-commerce Web site.

- H18: There is not a significant difference between the two generations' perception of the relationship between the behavioral intention to use an e-commerce Web site and the actual use of an e-commerce Web site.

\section{Participants \& Procedure}

During the Spring 2008 semester, the authors conducted a field experiment with a purposeful sample of students enrolled in four courses in the School of Information Technology at Macon State College. Because this research involved human subjects, Institutional Review Board approval was obtained before the study was conducted. At the time of data collection, the participants were taking courses in Project Management and Systems Analysis and Design, as well as a Senior Capstone course. To encourage participation, the students were given extra credit toward their final grade. 
Duplicating Smith's (2008) field experiment conducted with senior citizens, our participants searched for and selected products, either an airline trip or a book, from four retail Web sites in two industries - travel and online bookstores. The same Web sites were used - Orbitz.com, Travelocity.com, Booksamillion.com, and Barnesandnoble.com. The same sets of instructions detailing the tasks to be accomplished were used for each of the four e-commerce Web sites and each participant followed the instructions and executed the steps necessary to identify and select a book or an airline trip.

The four Web sites were tested by each participant in random order, reducing the influence of maturation effects (Sekaran, 2003). After each test on each Web site was completed, a researcher provided the post-task questionnaire to the participant to capture quantitative data about that shopping experience and that Web site. Neither study required the participant to complete the purchase of a book or an airline reservation by submission of credit card information, consistent with prior research (Agarwal \& Venkatesh, 2002; Chen, 2003; Gefen et al., 2000, 2003; Liang \& Lai, 2002; Smith, 2008).

\section{Data Collection}

Guided by the steps in the test script, each participant conducted the product searches by performing the same tasks. The participant followed the task instructions to select a book on the bookstore Web sites and to select an airline trip on the travel Web sites and then completed a questionnaire to capture information about the search and selection experience on the Web site. The researcher made every effort to see to it that every participant felt comfortable with the test environment and the test process. The goal was to minimize or eliminate any obstacles that could prevent the participant from successfully completing the task scenarios.

The researchers did not answer any questions on how to navigate or use the Web site nor did the researchers in any way bias or influence any participant's answers to the questionnaires. Participants could decide at any time to stop or abandon a product search on any of the four test Web sites. If that happened, the participant could choose to complete the post-task questionnaire on that experience.

After completing any product search and post-task questionnaire, the participant was allowed to stop, rest, and even arrange to resume at a later time or date. The quantitative data collected on any Web site test were used, although clearly data from all four Web sites were desired. Because this was a test about e-commerce Web site usability, quantitative data collected from any product search on any of the Web sites were used in the data analysis and final report. The 49 students completed a total of 189 post-task questionnaire responses.

\section{Instruments}

The two questionnaires that were used and validated in Smith's (2008) study with participation by senior citizens were also used in our study. A "Demographic and Computer Usage" questionnaire was used to capture demographic information about each participant and each participant's experience using computers and the Internet. The questions about how the participants learned to use the Internet and computers were modified slightly for this study to include schools - elementary, middle, high, and college - as potential sources of instruction.

The second questionnaire, called the "Post-task Questionnaire," was used to capture the participant's impression of the shopping experience on each of the four Web sites used in the study. Three questions on Web Site Usability were negatively worded, reducing the tendency for participants to always respond toward the same end of the scale (Sekaran, 2003). No changes were made to this questionnaire. 
A 7-point Likert scale was used to capture the responses to the construct questions. The range of the scale for the post-task questionnaire was from 1 to 7, from "strongly disagree" to "strongly agree" respectively. The range of the scale on the "Demographic and Computer Usage" questionnaire, used to capture information about the number of purchases made using e-commerce Web sites, was also from 1 to 7 , from having made " 0 " purchases to having made purchases "More than 10 times" respectively.

\section{Results Analysis}

The data collected on the post-task questionnaires were analyzed using PLS-Graph version 03.00 Build 1130. Microsoft Excel was used to format the input files for PLS-Graph, to compute the means and standard deviations for each Web site test, and to document the demographic characteristics of the participants.

PLS-Graph takes a conservative modeling approach that uses ordinary least squares regressions to estimate the loadings between items and constructs, the path coefficients, and the correlations between the constructs in the proposed research model (Chin, 1998). The output from PLSGraph was used for testing the significance of the causal paths and construct relationships.

The statistical significance of the path coefficients between the constructs was used to either "reject" or "not reject" the null hypotheses. Path coefficients, produced as output from PLS-Graph, were interpreted as regression coefficients in multiple regression analysis (Kline, 2005; Smith, 2008). PLS-Graph also calculated $t$-values that were used in testing the significance of the hypothesized relationships (Gefen et al., 2000; Smith, 2008).

The statistical significance is based on the selection of the significance level of the test. The significance level or alpha $(\alpha)$ was set at .05, a conventional level (J. Cohen, 1988; Kline, 2004), which establishes the probability of making a Type I error. A Type I error is the probability of incorrectly rejecting a true null hypothesis (J. Cohen, 1988; Kline, 2004). For this study, there is only a small probability $(<5 \%)$ that a true hypothesis will be falsely rejected. The probability of making a Type II error or failing to reject a false null hypothesis (J. Cohen, 1988; Kline, 2004) was not determined prior to conducting this study.

\section{Results}

\section{Descriptive Statistics}

The 49 students that participated in our study averaged 23 years of age and ranged in age from 21 to 31 years old. By comparison, the 21 senior citizens that participated in Smith's (2008) study averaged 76 years of age and ranged in age from 66 to 86 years. See Table 1 for demographic comparisons of the two groups of participants.

There are interesting but not unexpected differences between the participants in the two studies. The students chose "Self-Taught" when responding about how they learned to use a computer $(82 \%)$ and how they learned to use the Internet (90\%). The senior citizens, not surprisingly, for both questions chose "Training Class," $86 \%$ and $76 \%$ respectively. Ninety-two percent of the students have high-speed Internet connections, compared to only $43 \%$ of the senior citizens. 
Table 1: Descriptive Statistics of Participants

\begin{tabular}{|c|c|c|c|c|}
\hline \multicolumn{2}{|l|}{ Participant Characteristics } & Seniors & $\begin{array}{r}\text { Net } \\
\text { Generation }\end{array}$ & \\
\hline \multicolumn{2}{|l|}{ Number of Participants } & 21 & 49 & \\
\hline \multirow[t]{2}{*}{ Age } & Range in years & 66 to 86 & 21 to 31 & \\
\hline & Average in years & 76 & 23 & \\
\hline \multirow[t]{2}{*}{ Gender } & Male & $19 \%$ & $59 \%$ & \\
\hline & Female & $81 \%$ & $41 \%$ & \\
\hline \multirow[t]{2}{*}{ Own a Computer } & Yes & $100 \%$ & $96 \%$ & \\
\hline & No & $0 \%$ & $4 \%$ & \\
\hline \multirow[t]{4}{*}{ * Learn to use a computer } & Family Member & $43 \%$ & $39 \%$ & \\
\hline & Friend & $24 \%$ & $39 \%$ & \\
\hline & Training Class & $86 \%$ & $49 \%$ & \\
\hline & Self-Taught & $43 \%$ & $82 \%$ & \\
\hline \multirow[t]{5}{*}{ * Taken a computer class } & LLI & $10 \%$ & $8 \%$ & ES \\
\hline & SeniorNet & $38 \%$ & $8 \%$ & MS \\
\hline & Local School & $29 \%$ & $25 \%$ & HS \\
\hline & Other & $10 \%$ & $50 \%$ & College \\
\hline & & & $8 \%$ & Other \\
\hline \multirow[t]{4}{*}{ * Learn to use the Internet } & Family Member & $38 \%$ & $29 \%$ & \\
\hline & Friend & $24 \%$ & $37 \%$ & \\
\hline & Training Class & $76 \%$ & $29 \%$ & \\
\hline & Self-Taught & $43 \%$ & $90 \%$ & \\
\hline \multirow[t]{5}{*}{ * Taken an Internet training class } & LLI & $14 \%$ & $7 \%$ & ES \\
\hline & SeniorNet & $43 \%$ & $7 \%$ & MS \\
\hline & Local School & $14 \%$ & $21 \%$ & HS \\
\hline & Other & $5 \%$ & $36 \%$ & College \\
\hline & & & $29 \%$ & Other \\
\hline \multirow[t]{4}{*}{ * Connect to the Internet } & Home & $95 \%$ & $92 \%$ & \\
\hline & LLI & $0 \%$ & $96 \%$ & School \\
\hline & SeniorNet & $14 \%$ & $55 \%$ & Library \\
\hline & Other & $5 \%$ & $47 \%$ & \\
\hline \multirow[t]{3}{*}{ * Type of Internet connection } & Dial-up & $52 \%$ & $4 \%$ & \\
\hline & High-speed & $43 \%$ & $92 \%$ & \\
\hline & Don't know & $10 \%$ & $2 \%$ & \\
\hline
\end{tabular}

* Can add up to more than $100 \%$ since multiple answers are allowed.

** Abbreviations

LLI = Lifelong Learning Institute, Nova Southeastern University;

ES = Elementary School; MS = Middle School; HS = High School 
Pertaining to Internet usage (see Table 2) $62 \%$ of the seniors indicated that they use the Internet daily, compared to $98 \%$ of the students. Forty-eight percent of the seniors have used the Internet for over three years whereas $100 \%$ of the students reported having used the Internet for more than three years. Interestingly, $62 \%$ of the seniors indicated that they have made a purchase over the Internet, compared to $96 \%$ of the students. Twenty-nine percent of the seniors previously purchased a book using an online bookstore and $48 \%$ of them used the Internet to make an airline reservation. Fifty-five percent of the students previously purchased a book using an online bookstore and only $27 \%$ of them used the Internet to make an airline reservation.

Table 2: Internet Usage by Participants

\begin{tabular}{|c|c|c|c|}
\hline Internet Usage & & Seniors & $\begin{array}{r}\text { Net } \\
\text { Generation }\end{array}$ \\
\hline Number of Participants & & 21 & 49 \\
\hline \multirow[t]{4}{*}{ The Internet is used... } & Daily & $62 \%$ & $98 \%$ \\
\hline & Weekly & $24 \%$ & $2 \%$ \\
\hline & Monthly & $0 \%$ & $0 \%$ \\
\hline & Other & $14 \%$ & $0 \%$ \\
\hline \multirow[t]{2}{*}{ Used the Internet in the past six months } & Yes & $100 \%$ & $100 \%$ \\
\hline & No & $0 \%$ & $0 \%$ \\
\hline \multirow[t]{4}{*}{ Has been a user of the Internet } & $<1$ year & $33 \%$ & $0 \%$ \\
\hline & $1-2$ years & $10 \%$ & $0 \%$ \\
\hline & $2-3$ years & $10 \%$ & $0 \%$ \\
\hline & $>3$ years & $48 \%$ & $100 \%$ \\
\hline \multirow{7}{*}{$\begin{array}{l}\text { The number of times during the past } \\
\text { year that a purchase was made using the } \\
\text { Internet }\end{array}$} & None & $38 \%$ & $4 \%$ \\
\hline & $1-2$ times & $29 \%$ & $16 \%$ \\
\hline & $3-4$ times & $10 \%$ & $16 \%$ \\
\hline & $5-6$ times & $10 \%$ & $18 \%$ \\
\hline & 7 - 8 times & $5 \%$ & $10 \%$ \\
\hline & $9-10$ times & $0 \%$ & $12 \%$ \\
\hline & $>10$ times & $10 \%$ & $22 \%$ \\
\hline \multirow[t]{7}{*}{ Used the internet to purchase a book } & None & $71 \%$ & $45 \%$ \\
\hline & $1-2$ times & $10 \%$ & $24 \%$ \\
\hline & $3-4$ times & $0 \%$ & $20 \%$ \\
\hline & $5-6$ times & $14 \%$ & $8 \%$ \\
\hline & 7 - 8 times & $0 \%$ & $0 \%$ \\
\hline & $9-10$ times & $5 \%$ & $0 \%$ \\
\hline & $>10$ times & $0 \%$ & $2 \%$ \\
\hline \multirow{7}{*}{$\begin{array}{l}\text { Used the Internet to make an airline } \\
\text { reservation }\end{array}$} & None & $52 \%$ & $73 \%$ \\
\hline & $1-2$ times & $29 \%$ & $12 \%$ \\
\hline & $3-4$ times & $5 \%$ & $8 \%$ \\
\hline & $5-6$ times & $10 \%$ & $4 \%$ \\
\hline & 7 - 8 times & $0 \%$ & $2 \%$ \\
\hline & $9-10$ times & $5 \%$ & $0 \%$ \\
\hline & $>10$ times & $0 \%$ & $0 \%$ \\
\hline
\end{tabular}




\section{Test of Model and Hypotheses}

The responses to the questionnaires were keyed into an Excel spreadsheet. The responses to the negatively worded items, numbers 23, 24, and 25 on the construct Web Site Usability, were reversed during data entry. The spreadsheet was then used as data input to the PLS-Graph program, and the program generated the path coefficients, $t$ statistics, and variances using a bootstrapping resampling technique. Bootstrapping is a standard approach used by PLS-Graph that resamples with replacement from the original sample and for this study 500 resamples were used for significance testing of the path estimates (Chin, 1998).

The result of that analysis using the proposed research model is shown in Figure 4. The figure presents the amount of variance $\left(R^{2}\right)$ explained in the dependent constructs (Perceived Usefulness of the Web Site, Perceived Ease of Use of the Web Site, Attitude Toward Using the Web Site, Behavioral Intention to Use the Web Site, and Actual System Usage of the Web Site) and the path coefficients for the dependent and independent construct relationships.

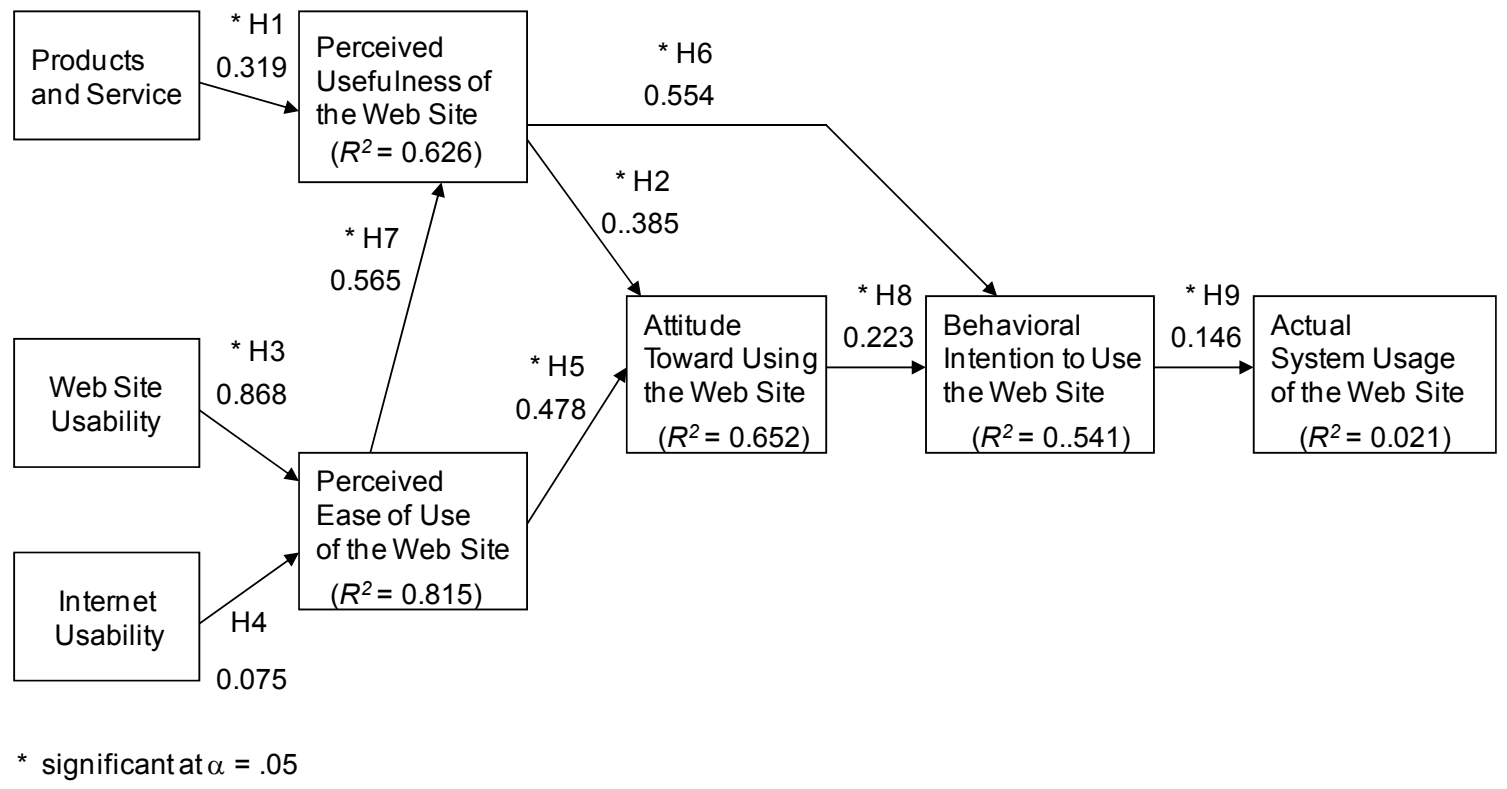

Figure 4. Hypotheses and Model Parameters for Net Generation

The statistical significance of the causal path between the constructs was determined using $t$ statistics generated by PLS-Graph and was used to either "reject" or "not reject" the null hypotheses. The $t$ distribution table, using a one-tailed test, $\alpha=.05$, and a degrees of freedom of $188(n-1)$, was used to determine the critical value. If the $t$ statistic was greater than the critical value of 1.653 , the null hypothesis was not rejected. If the $t$ statistic was less than or equal to the critical value of 1.653 , the hypothesis was rejected. Of the nine hypotheses, eight were rejected and one was not rejected.

The nine null hypotheses and the results of the findings are as follows:

- H1: The net generation's perception of the products and services offered by an ecommerce Web site will not have a significant effect on the net generation's perceived usefulness of an e-commerce Web site.

The path coefficient between the construct Products and Services and the construct Perceived Usefulness of the Web Site is significant at 0.319 ( $t$ statistic $=4.843)$. H1 should be rejected. 
- H2: The net generation's perception of the perceived usefulness of an e-commerce Web site will not have a significant effect on the net generation's attitude toward using an ecommerce Web site.

The path coefficient between the construct Perceived Usefulness of the Web Site and the construct Attitude Toward Using the Web Site is significant at $0.385(t$ statistic $=4.505)$. $\mathrm{H} 2$ should be rejected.

- H3: The net generation's perception of the usability of an e-commerce Web site will not have a significant effect on the net generation's perceived ease of use of an e-commerce Web site.

The path coefficient between the construct Web Site Usability and the construct Perceived Ease of Use of the Web Site is significant at $0.868(t$ statistic $=25.425)$. H3 should be rejected.

- H4: The net generation's perception of the usability of the Internet will not have a significant effect on the net generation's perceived ease of use of an e-commerce Web site.

The path coefficient between the construct Internet Usability and the construct Perceived Ease of Use of the Web Site is not significant at 0.075 ( $t$ statistic =1.549). H4 should not be rejected.

- H5: The net generation's perceived ease of use of an e-commerce Web site will not have a significant effect on the net generation's attitude toward using an e-commerce Web site.

The path coefficient between the construct Perceived Ease of Use of the Web Site and the construct Attitude Toward Using the Web Site is significant at 0.478 ( $t$ statistic $=5.498)$. H5 should be rejected.

- H6: The net generation's perceived usefulness of an e-commerce Web site will not have a significant effect on the net generation's behavioral intention to use an e-commerce Web site.

The path coefficient between the construct Perceived Usefulness of the Web Site and the construct Behavioral Intention to Use the Web Site is significant at 0.554 ( $t$ statistic $=$ 6.583). H6 should be rejected.

- H7: The net generation's perceived ease of use of an e-commerce Web site will not have a significant effect on the net generation's perceived usefulness of an e-commerce Web site.

The path coefficient between the construct Perceived Ease of Use of the Web Site and the construct Perceived Usefulness of the Web Site is significant at 0.565 ( $t$ statistic $=7.852)$. H7 should be rejected.

- H8: The net generation's attitude toward using an e-commerce Web site will not have a significant effect on the net generation's behavioral intention to use an e-commerce Web site.

The path coefficient between the construct Attitude Toward Using the Web Site and the construct Behavioral Intention to Use the Web Site is significant at $0.223(t$ statistic $=$ 2.792). H8 should be rejected.

- H9: The net generation's behavioral intention to use an e-commerce Web site will not have a significant effect on predicting the net generation's actual use of an e-commerce Web site. 
The path coefficient between the construct Behavioral Intention to Use the Web Site and the construct Actual System Usage of the Web Site is significant at $0.146(t$ statistic $=$ 1.680). H9 should be rejected.

Given that statistically significant results were not found for null hypothesis H4, it was important to estimate the probability that a Type II error occurred. The power of a statistical test is the probability of making a decision to reject a null hypothesis when it is false and the probability that a Type II error occurred is the complement of the statistical power (J. Cohen, 1988; Kline, 2004). In a post hoc power analysis, three parameters are used to compute the power of the test and the probability that a Type II error occurred. The parameters are: 1) the sample size; 2) the alpha level; and 3) the effect size. The effect size is the strength of the relationship among the independent and dependent constructs being tested in each of the null hypotheses (Kline, 2004) and is provided in the output of PLS-Graph as Pearson correlation coefficients. To determine the power of the test and the probability of a Type II error, J. Cohen's (1988) Pearson productmoment correlation power table can be used when all three of the parameters are known.

Pertaining to $\mathrm{H} 4$, the Pearson correlation between the net generations' perception of the usability of the Internet and the net generation's perceived ease of use of an e-commerce Web site was 0.075. In this study, the sample size was 189 data cases and the alpha level was set at .05. Using J. Cohen's (1988) power table and a one-tailed test, the power of this test was $<=.392$ and the probability of a Type II error was $>.608$.

The research model contains many dependent-independent construct relationships that were also analyzed using PLS-Graph. The relationships and the findings are as follows:

- Sixty-three percent of variance in the dependent construct Perceived Usefulness of the Web Site is explained by two independent constructs, Perceived Ease of Use of the Web Site and Products and Services. The path coefficients indicate that between the two independent constructs, Perceived Ease of Use of the Web Site exerts a much greater influence (0.565) than does Products and Services (0.319).

- Eighty-one percent of variance in the dependent construct Perceived Ease of Use of the Web Site is explained by two independent constructs, Web Site Usability and Internet Usability. The path coefficients indicate that between the two independent constructs, $W e b$ Site Usability exerts a greater influence (0.868) than does Internet Usability (0.075).

- Sixty-five percent of variance in the dependent construct Attitude toward Using the Web Site is explained by two independent constructs, Perceived Ease of Use of the Web Site and Perceived Usefulness of the Web Site. The path coefficients indicate that between the two independent constructs, Perceived Ease of Use of the Web Site exerts a greater influence (0.478) than does Perceived Usefulness of the Web Site (0.385).

- Fifty-four percent of variance in the dependent construct Behavioral Intention to Use the Web Site is explained by two independent constructs, Perceived Usefulness of the Web Site and Attitude Toward Using the Web Site. The path coefficients indicate that between the two independent constructs, Perceived Usefulness of the Web Site exerts a greater influence (0.554) than does Attitude Toward Using the Web Site (0.223).

- Less than one percent of the variance in the primary dependent construct Actual System Usage of the Web Site is explained by the independent construct, Behavioral Intention to Use the Web Site (0.146).

Table 6 presents a summary of the two studies and answers the first of the two research questions: Are there any significant differences between the two generations' perceptions of e-commerce 
Web sites as defined by the research model? The decision to reject or to not reject the null hypothesis is listed under each group of participants.

Table 6. Research Question 1

\begin{tabular}{|c|c|c|}
\hline Null Hypotheses & $\begin{array}{c}\text { Senior } \\
\text { Generation }\end{array}$ & $\begin{array}{c}\text { Net } \\
\text { Generation }\end{array}$ \\
\hline $\begin{array}{l}\text { H1: The perception of the products and services offered by an } \\
\text { e-commerce Web site will not have a significant effect on the } \\
\text { perceived usefulness of an e-commerce Web site. }\end{array}$ & Rejected & Rejected \\
\hline $\begin{array}{l}\text { H2: The perception of the perceived usefulness of an e- } \\
\text { commerce Web site will not have a significant effect on the } \\
\text { attitude toward using an e-commerce Web site. }\end{array}$ & Rejected & Rejected \\
\hline $\begin{array}{l}\text { H3: The perception of the usability of an e-commerce Web } \\
\text { site will not have a significant effect on the perceived ease of } \\
\text { use of an e-commerce Web site. }\end{array}$ & Rejected & Rejected \\
\hline $\begin{array}{l}\text { H4: The perception of the usability of the Internet will not } \\
\text { have a significant effect on the perceived ease of use of an e- } \\
\text { commerce Web site. }\end{array}$ & Rejected & $\begin{array}{c}\text { Not } \\
\text { Rejected }\end{array}$ \\
\hline $\begin{array}{l}\text { H5: The perceived ease of use of an e-commerce Web site } \\
\text { will not have a significant effect on the attitude toward using } \\
\text { an e-commerce Web site. }\end{array}$ & Rejected & Rejected \\
\hline $\begin{array}{l}\text { H6: The perceived usefulness an e-commerce Web site will } \\
\text { not have a significant effect on the behavioral intention to use } \\
\text { an e-commerce Web site. }\end{array}$ & Rejected & Rejected \\
\hline $\begin{array}{l}\text { H7: The perceived ease of use of an e-commerce Web site } \\
\text { will not have a significant effect on the perceived usefulness } \\
\text { of an e-commerce Web site. }\end{array}$ & $\begin{array}{c}\text { Not } \\
\text { Rejected }\end{array}$ & Rejected \\
\hline $\begin{array}{l}\text { H8: The attitude toward using an e-commerce Web site will } \\
\text { not have a significant effect on the behavioral intention to use } \\
\text { an e-commerce Web site. }\end{array}$ & $\begin{array}{c}\text { Not } \\
\text { Rejected }\end{array}$ & Rejected \\
\hline $\begin{array}{l}\text { H9: The behavioral intention to use an e-commerce Web site } \\
\text { will not have a significant effect on predicting the actual use } \\
\text { of an e-commerce Web site. }\end{array}$ & $\begin{array}{c}\text { Not } \\
\text { Rejected }\end{array}$ & Rejected \\
\hline
\end{tabular}

\section{Other Research Question}

Our study also answers a second research question: Are there any significant differences between the two generations' perceptions of the construct relationships as defined by the research model? Significance testing of the difference between the two correlations on the variable relationships was conducted, resulting in a $z$ value (Sekaran, 2003). Using a two-tailed test of the normal distribution and $\alpha=.05$, we would reject the null hypothesis only if $z>1.96$ or $z<-1.96$. The results are as follows:

- H10. There is not a significant difference between the two generations' perceptions of the relationship between the products and services offered by an e-commerce Web site and the perceived usefulness of an e-commerce Web site. 
The correlation in the senior generation study was 0.688 and the correlation in the net generation study was 0.319 , resulting in a $\mathrm{z}=3.64$. H10 should be rejected.

- H11: There is not a significant difference between the two generations' perceptions of the relationship between the perceived usefulness of an e-commerce Web site have and the attitude toward using an e-commerce Web site.

The correlation in the senior generation study was 0.253 and the correlation in the net generation study was 0.385 , resulting in a $\mathrm{z}=1.05$. H11 should not be rejected.

- H12: There is not a significant difference between the two generations' perception of the relationship between the usability of an e-commerce Web site and the perceived ease of use of an e-commerce Web site.

The correlation in the senior generation study was 0.711 and the correlation in the net generation study was 0.868 , resulting in a $\mathrm{z}=3.09$. H12 should be rejected.

- H13: There is not a significant difference between the two generations' perception of the relationship between the usability of the Internet and the perceived ease of use of an ecommerce Web site.

The correlation in the senior generation study was 0.296 and the correlation in the net generation study was 0.075 , resulting in a $\mathrm{z}=1.63$. H13 should not be rejected.

- H14: There is not a significant difference between the two generations' perception of the relationship between the perceived ease of use of an e-commerce Web site and the attitude toward using an e-commerce Web site.

The correlation in the senior generation study was 0.647 and the correlation in the net generation study was 0.478 , resulting in a $\mathrm{z}=1.77$. H14 should not be rejected.

- H15: There is not a significant difference between the two generations' perception of the relationship between the perceived usefulness of an e-commerce Web site and the behavioral intention to use an e-commerce Web site.

The correlation in the senior generation study was 0.643 and the correlation in the net generation study was 0.554 , resulting in a $\mathrm{z}=0.98$. H15 should not be rejected.

- H16: There is not a significant difference between the two generations' perception of the relationship between the perceived ease of use of an e-commerce Web site and the perceived usefulness of an e-commerce Web site.

The correlation in the senior generation study was 0.151 and the correlation in the net generation study was 0.565 , resulting in a $\mathrm{z}=3.46$. H16 should be rejected.

- H17: There is not a significant difference between the two generations' perception of the relationship between the attitude toward using an e-commerce Web site and the behavioral intention to use an e-commerce Web site.

The correlation in the senior generation study was 0.184 and the correlation in the net generation study was 0.223 , resulting in a $\mathrm{z}=0.29$. H17 should not be rejected.

- H18: There is not a significant difference between the two generations' perception of the relationship between the behavioral intention to use an e-commerce Web site and the actual use of an e-commerce Web site.

The correlation in the senior generation study was 0.063 and the correlation in the net generation study was 0.146 , resulting in a $\mathrm{z}=0.60$. H18 should not be rejected. 
Table 7 presents a summary of the findings for the second of the two research questions: Are there any significant differences between the two generations' perceptions of the construct relationships as defined by the research model?

Table 7. Research Question 2

\begin{tabular}{|c|c|}
\hline Null Hypotheses & Result \\
\hline $\begin{array}{l}\text { H10: There is not a significant difference between the two } \\
\text { generations' perceptions of the relationship between the prod- } \\
\text { ucts and services offered by an e-commerce Web site and the } \\
\text { perceived usefulness of an e-commerce Web site. }\end{array}$ & Rejected \\
\hline $\begin{array}{l}\text { H11: There is not a significant difference between the two } \\
\text { generations' perceptions of the relationship between the per- } \\
\text { ceived usefulness of an e-commerce Web site have and the at- } \\
\text { titude toward using an e-commerce Web site. }\end{array}$ & $\begin{array}{c}\text { Not } \\
\text { Rejected }\end{array}$ \\
\hline $\begin{array}{l}\text { H12: There is not a significant difference between the two } \\
\text { generations' perception of the relationship between the usabil- } \\
\text { ity of an e-commerce Web site and the perceived ease of use } \\
\text { of an e-commerce Web site. }\end{array}$ & Rejected \\
\hline $\begin{array}{l}\text { H13: There is not a significant difference between the two } \\
\text { generations' perception of the relationship between the usabil- } \\
\text { ity of the Internet and the perceived ease of use of an e- } \\
\text { commerce Web site. }\end{array}$ & $\begin{array}{c}\text { Not } \\
\text { Rejected }\end{array}$ \\
\hline $\begin{array}{l}\text { H14: There is not a significant difference between the two } \\
\text { generations' perception of the relationship between the per- } \\
\text { ceived ease of use of an e-commerce Web site and the attitude } \\
\text { toward using an e-commerce Web site. }\end{array}$ & $\begin{array}{c}\text { Not } \\
\text { Rejected }\end{array}$ \\
\hline $\begin{array}{l}\text { H15: There is not a significant difference between the two } \\
\text { generations' perception of the relationship between the per- } \\
\text { ceived usefulness of an e-commerce Web site and the behav- } \\
\text { ioral intention to use an e-commerce Web site. }\end{array}$ & $\begin{array}{c}\text { Not } \\
\text { Rejected }\end{array}$ \\
\hline $\begin{array}{l}\text { H16: There is not a significant difference between the two } \\
\text { generations' perception of the relationship between the per- } \\
\text { ceived ease of use of an e-commerce Web site and the per- } \\
\text { ceived usefulness of an e-commerce Web site. }\end{array}$ & Rejected \\
\hline $\begin{array}{l}\text { H17: There is not a significant difference between the two } \\
\text { generations' perception of the relationship between the atti- } \\
\text { tude toward using an e-commerce Web site and the behavioral } \\
\text { intention to use an e-commerce Web site. }\end{array}$ & $\begin{array}{c}\text { Not } \\
\text { Rejected }\end{array}$ \\
\hline $\begin{array}{l}\text { H18: There is not a significant difference between the two } \\
\text { generations' perception of the relationship between the behav- } \\
\text { ioral intention to use an e-commerce Web site and the actual } \\
\text { use of an e-commerce Web site. }\end{array}$ & $\begin{array}{c}\text { Not } \\
\text { Rejected }\end{array}$ \\
\hline
\end{tabular}




\section{Findings and Conclusions}

The findings in our study are unique in many ways. First, this is the only study we know of that compares two generations and their perceptions of e-commerce Web sites.

Consistent with the conclusion by Smith (2008), of significant worth is the test of the robustness of the Technology Acceptance Model (TAM) when applied to e-commerce adoption by both the senior generation and the net generation. The model's predictive and explanatory capabilities still hold true. In both studies useful Web sites have products or services that consumers need or want. The relationship between a Web site's perceived usefulness and the behavioral intention to use the Web site is still strong. The long established causal relationship between perceived ease of use and attitude toward using the Web site was also strong. Web site usability was shown, in both studies, to exert the greatest influence on the perceived ease of use of the Web sites.

Two factors were posited to influence a participant's perception of the ease of use of the Web site, the constructs Web Site Usability and Internet Usability. In both studies, the path coefficients indicate that between the two independent constructs, Web Site Usability exerts a greater influence than does Internet Usability. Surprisingly, the net generation did not find that Internet usability has a significant influence on the perceived ease of use of the Web site. One explanation might be that the net generation has grown up using the Internet and has learned how to overcome any problems they encounter when using the Internet. This suggests that experience using the Internet does make a difference. Web site usability, on the other hand, is more important to the net generation than it is to the senior generation. This finding surprised the authors, who expected the opposite to be true. Considering the challenges people face as they age, including changes in vision and motor skills, we expected the senior generation to value Web site usability higher than the members of the net generation.

Three of the nine null hypotheses were not rejected in Smith's (2008) study - H7, H8, and H9 but were rejected in our study. Specific to H7, the net generation study found that that perceived ease of use does have a significant effect on perceived usefulness, a finding that tends to change from one TAM study to another. Pertaining to H8, the net generations' attitude toward using an e-commerce Web site does have a significant effect on the behavioral intention to use an ecommerce Web site. Finally, specific to H9, the net generation's behavioral intention to use an ecommerce Web site does have a significant effect on predicting the actual use of an e-commerce Web site.

The results in our study suggest e-commerce organizations should take online purchasing experience into account as they develop their Web sites. As noted earlier, $62 \%$ of the seniors indicated that they have made a purchase over the Internet, compared to $96 \%$ of the students. Twenty-two percent of the students have shopped on the Internet more than 10 times, compared to only $10 \%$ of the seniors. Consistent with Klopping and McKinney (2006) and Ranganathan and Jha (2007), it appears that actual online shopping experience directly leads net generation shoppers to continue to shop online.

The answer as to why the actions against the four null hypotheses were different between the two studies may also be explained by the answers to the second research question - whether there was any significant difference in the way the two generations' perceived the effects of each of the relationships between the variables in the research model. The results of the null hypotheses H10 through H1 8 hold the answer.

Specific to the null hypothesis H10, there was a significant difference between the two generations' perceptions of the relationship between the products and services offered by an ecommerce Web site and the perceived usefulness of an e-commerce Web site. The relationship (as indicated by the correlation) was much stronger in the senior study when compared to the net 
generation results, suggesting that seniors will search for the right Web site with the appropriate products and services versus just surfing the Web.

Specific to the null hypothesis H12, there was a significant difference between the two generations' perceptions of the relationship between the usability of an e-commerce Web site and the perceived ease of use of an e-commerce Web site. The relationship (as indicated by the correlation) was much stronger in the net generation study when compared to the senior generation results. It should be mentioned, however, that although both coefficients were high and significant, this is somewhat surprising. The authors expected to see an opposite result.

Specific to null hypothesis H16, there was a significant difference between the two generations' perceptions of the relationship between the perceived ease of use of an e-commerce Web site and the perceived usefulness of an e-commerce Web site. The relationship (as indicated by the correlation) was significantly stronger in the net generation study when compared to the senior generation results, supporting many prior research findings that a Web site is not considered useful unless it is also easy to use.

In closing, E. Cohen (2009) states that "... the Informing Science philosophy is that broad, transdisciplinary research is needed to understand how best to use technology to inform clients" (p. 12). This study of user perceptions of e-commerce websites by two generations of users is one such example of that research.

\section{Limitations}

Although a number of conclusions have been drawn as a result of this study, it is important to review some of the limitations against which these conclusions should be judged. First, purposeful samples were used in both studies and this limits generalizability. Second, the participants may not adequately represent the net generation or the senior population in both Internet usage and Web expertise. Last of all, the four Web sites used in the testing came from two industries, travel and books, and may not fully represent the design, functionality, and usability of all of the types of e-commerce Web sites.

\section{Directions for Future Research}

Regarding future research, researchers should conduct studies that address the following:

1. Additional research is necessary to examine the generalizability of the findings by testing the research model with students from other classes. Collecting data across multiple classes would improve the generalizability.

2. Conduct the same study with a larger sample as a means of increasing the statistical power and reducing the potential for Type II error.

3. Conduct the same study with participants from the baby boomer generation, the generation that will be primarily responsible for the rapid growth in the senior population over the next two decades. It would be most interesting to see if Internet usability and/or Web site usability had the same or less of an influence on perceived ease of use of e-commerce Web sites when compared to the findings in this paper.

4. Alter the research model to remove the construct Actual System Usage of the Web Site and terminate the model with Behavioral Intention to Use the Web Site. The relationship between the two variables is the weakest in both studies. 
5. Remove the construct Attitude Toward Using the Web Site and instead posit that both the Perceived Ease of Use of the Web Site and the Perceived Usefulness of the Web Site directly affect the Behavioral Intention to Use the Web Site.

\section{References}

Agarwal, R., \& Venkatesh, V. (2002). Assessing a firm's Web presence: A heuristic evaluation procedure for the measurement of usability. Information Systems Research, 13(2), 168-186.

Burton-Jones, A., \& Hubona, G. S. (2005). Individual differences and usage behavior: Revisiting a technology acceptance model assumption. Database for Advances in Information Systems, 36(2), 58-77.

Chen, C. (2003). An investigation of significant factors affecting consumer trust in e-commerce. Dissertation Abstracts International, 64(9), 3376. (UMI No. 3106539).

Chin, W. H. (1998). Partial least squares approach to structural equation modeling. In G. A. Marcoulides (Ed.), Modern methods for business research (pp. 295-336). Mahwah, NJ: Lawrence Erlbaum Associates.

Cohen, E. B. (1999). Reconceptualizing information systems as a field of the transdiscipline informing science: From ugly duckling to swan. Journal of Computing and Information Technology, 7(3), 213-219.

Cohen, E. B. (2009). A philosophy of informing science. Informing Science: the International Journal of an Emerging Transdiscipline, 12, 1-15.

Cohen, J. (1988). Statistical power analysis for the behavioral sciences. Hillsdale, NJ: Lawrence Erlbaum Associates.

Davis, F. D. (1989). Perceived usefulness, perceived ease of use, and user acceptance of information technology. MIS Quarterly, 13(3), 319-340.

Devaraj, S., Fan, M., \& Kohli, R. (2002). Antecedents of B2C channel satisfaction and preference: Validating e-commerce metrics. Information Systems Research, 13(3), 316-333.

Fox, S. (2004). Older Americans and the Internet. Retrieved November 25, 2008, from http://www.pewinternet.org/pdfs/PIP_Seniors_Online_2004.pdf

Gefen, D., Karahanna, E., \& Straub, D. W. (2003). Trust and TAM online shopping: An integrated model. MIS Quarterly, 27(1), 51-90.

Gefen, D., Straub, D. W., \& Boudreau, M. (2000). Structural equation modeling and regression: Guidelines for research practice. Communication of AIS, 4(7), 2-77.

Gill, T. G. (2008). The single client resonance model: Beyond rigor and relevance. Informing Science: the International Journal of an Emerging Transdiscipline, 11, 281-310.

Hausman, A. V., \& Siekpe, J. S. (2009). The effect of web interface features on consumer purchase intentions. Journal of Business Research, 62(1), 5-13.

Kline, R. B. (2004). Beyond significance testing. Washington, DC: American Psychological Association.

Kline, R. B. (2005). Principles and practice of structural equation modeling ( $2^{\text {nd }}$ ed.). New York, NY: The Guilford Press.

Klopping, I. M., \& McKinney, E. (2006). Practice makes a difference: Experience and e-commerce. Information Technology: Learning and Performance Journal, 24(1), 25-37.

Koufaris, M. (2000). System Design and consumer behavior in electronic commerce. Dissertation Abstracts International, 61(9), 3661. (UMI No. 9988944).

Liang, T., \& Lai, H. (2002). Effect of store design on consumer purchases: An empirical study of on-line bookstores. Information \& Management, 39(6), 431-444. 
Morosan, C., \& Jeong, M. (2008). Users' perceptions of two types of hotel reservation Web sites. International Journal of Hospitality Management, 27(2), 284-292.

Ranganathan, C., \& Jha, S. (2007). Examining online purchase intentions in B2C e-commerce: Testing an integrated model. Information Resources Management Journal, 20(4), 48-64.

Rettie, R. (2002). Net generation culture. Journal of Electronic Commerce Research, 3(4), 254-263.

Savitskie, K., Royne, M. B., Persinger, E. S., Grunhagen, M., \& Witte, C. L. (2007). Norwegian Internet shopping sites: An application \& extension of the technology acceptance model. Journal of Global Information Technology Management, 10(4), 54-73.

Sekaran, U. (2003). Research methods for business: A skill-building approach. (4th ed.). Hoboken, NJ: John Wiley \& Sons.

Singh, N., Fassott, G., Chao, M. C. H., \& Hoffman, J. A. (2006). Understanding international Web site usage: A cross-national study of German, Brazilian, and Taiwanese online consumers. International Marketing Review, 23(1), 83-97.

Smith, T. J. (2008). Senior citizens and e-commerce websites: The role of perceived usefulness, perceived ease of use, and Web site usability. Informing Science: the International Journal of an Emerging Transdiscipline, 11, 59-83.

Venkatesh, V. (2000). Determinants of perceived ease of use: Integrating control, intrinsic motivation, and emotion into the technology acceptance model. Information Systems Research, 11(4), 342-365.

Zaphiris, P., \& Sarwar, R. (2006). Trends, similarities, and differences in the usage of teen and senior public online newsgroups. ACM Transactions on Computer-Human Interaction, 13(3), 403-422.

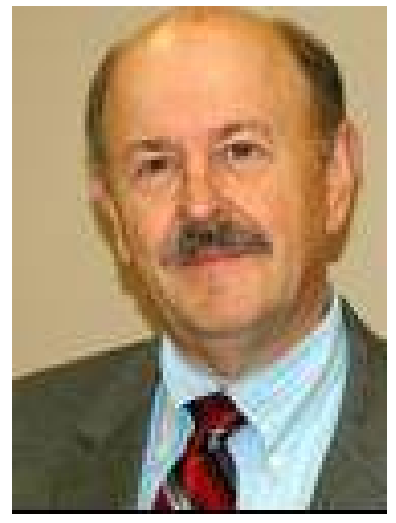

\section{Biographies}

Terry Smith is an assistant professor in the School of Information Technology at Macon State College in Macon, Georgia. He holds a Ph.D. in Information Systems from Nova Southeastern University in Ft. Lauderdale, Florida and a M.B.A. from the University of South Florida in Tampa, Florida. His research interests include humancomputer interaction, Web and Internet technologies, E-business, Ecommerce, E-government, and E-Learning.

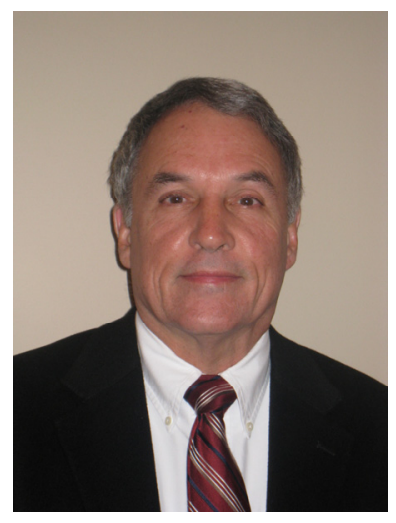

Richard Spiers is an associate professor in the School of Information Technology at Macon State College in Macon, Georgia. He holds a M.B.A. from the University of Southern Mississippi. His research interests include systems-theory and practice, experiential learning, and modeling. 